\title{
Epigenetic reprogramming during spermatogenesis and male factor infertility
}

\author{
H M McSwiggin ${ }^{1}$ and A M O'Doherty ${ }^{2}$ \\ ${ }^{1}$ Department of Physiology and Cell Biology, University of Nevada, Reno School of Medicine, Center for Molecular \\ Medicine, Reno, North Virginia, USA and ${ }^{2}$ Animal Genomics Laboratory, UCD School of Agriculture and Food \\ Science, University College Dublin, Dublin, Ireland
}

Correspondence should be addressed to A M O’Doherty; Email: alan.odoherty@ucd.ie

\begin{abstract}
Infertility is an often devastating diagnosis encountered by around one in six couples who are trying to conceive. Moving away from the long-held belief that infertility is primarily a female issue, it is now recognised that half, if not more, of these cases may be due to male factors. Recent evidence has suggested that epigenetic abnormalities in chromatin dynamics, DNA methylation or sperm-borne RNAs may contribute to male infertility. In light of advances in deep sequencing technologies, researchers have been able to increase the coverage and depth of sequencing results, which in turn has allowed more comprehensive analyses of spermatozoa chromatin dynamics and methylomes and enabled the discovery of new subsets of sperm RNAs. This review examines the most current literature related to epigenetic processes in the male germline and the associations of aberrant modifications with fertility and development. Reproduction (2018) 156 R9-R21
\end{abstract}

\section{Introduction}

Male infertility is a complex disease that, despite being extensively researched, still remains poorly understood. Although infertility can be attributed to decreased semen quality, testicular dysfunction, infections of the genital tract and known genetic disorders (such as single-gene alterations and chromosomal abnormalities) (Krausz et al. 2015), a number of male patients suffer from a condition known as idiopathic or unexplained male infertility (UMI), in which the aetiology is poorly understood (Urdinguio et al. 2015). Given the major genome reprogramming events that occur during gametogenesis and early development, in recent years, a number of studies have pointed towards aberrant epigenetic reprogramming of the genome as a potential contributory factor to male infertility (O'Doherty \& McGettigan 2014, Laurentino et al. 2015, Stuppia et al. 2015, Urdinguio et al. 2015, Schagdarsurengin \& Steger 2016, Kropp et al. 2017, Laqqan et al. 2017a, Nasri et al. 2017). It should be stressed that, at present, direct associations between epigenetic changes and infertility are unclear - it is indeed possible that they are simply correlated with changes in infertility and not causal.

There are currently a variety of definitions and opinions on the term 'Epigenetics', which can often stir debate. A widely used and accepted definition of epigenetic processes is one that defines them as heritable changes influencing gene expression that are not caused by changes to DNA sequence (Holliday 1987). These processes lead to the establishment of specialised chromatin states that are permissive or repressive to gene expression, can be influenced by the maternal or paternal environment due to their plasticity and are involved with determining cell identity (Schagdarsurengin \& Steger 2016, Stewart et al. 2016). To date, DNA methylation has been the most comprehensively studied epigenetic mark (Smith \& Meissner 2013), however, posttranslational modifications to histone tails and the role of non-coding RNA molecules (both widely regarded as epigenetic processes/modifications) are gaining considerable attention.

Determining the underlying causes of unknown male factor infertility still remains a major challenge in reproductive medicine (Salas-Huetos et al. 2016). In the clinical setting, widely used semen analysis methods for diagnosing male factor infertility, such as microscopic examination and DNA fragmentation analyses, do not tell the whole story. These approaches are mostly ineffective for diagnosing UMI, where spermiograms of normozoospermic infertile patients are indistinguishable from those of normozoospermic fertile patients (Hamada et al. 2012). However, recent advancements in sequencing technologies have allowed researchers to evaluate the sperm epigenome and build a bigger picture of their underlying molecular profiles, helping to determine why some couples experience idiopathic infertility.

In this review, we will focus on the potential role of aberrant epigenetic reprogramming of the sperm 
genome on male fertility and early development, with particular emphasis on DNA methylation, histone tail modifications and non-coding RNA molecules (Fig. 1).

\section{Epigenetic reprogramming during sperm development}

The genome is extensively remodelled during mammalian germ cell development in both male and female germlines, and this epigenetic reprogramming is critical for imprinting and reprogramming in early embryos (Reik et al. 2001). Chromatin organisation in sperm and oocytes is markedly different: sperm DNA is tightly packed, histones are largely replaced with protamines and there is a large degree of DNA methylation while oocytes have less DNA methylated and prevalently open chromatin (O'Doherty \& McGettigan 2014, Bao \& Bedford 2016, Hanna \& Kelsey 2017). Given that the emphasis of the current review is on epigenetic mechanisms during spermatogenesis and male fertility, we will be focusing solely on the paternal germline. For a comprehensive review on genome reprogramming in the female germline, see Messerschmidt et al. 2014, Stewart et al. 2016.

There are two major reprogramming events that involve genome-wide erasure and re-establishment of DNA methylation patterns during mammalian development; the first occurs in primordial germ cells

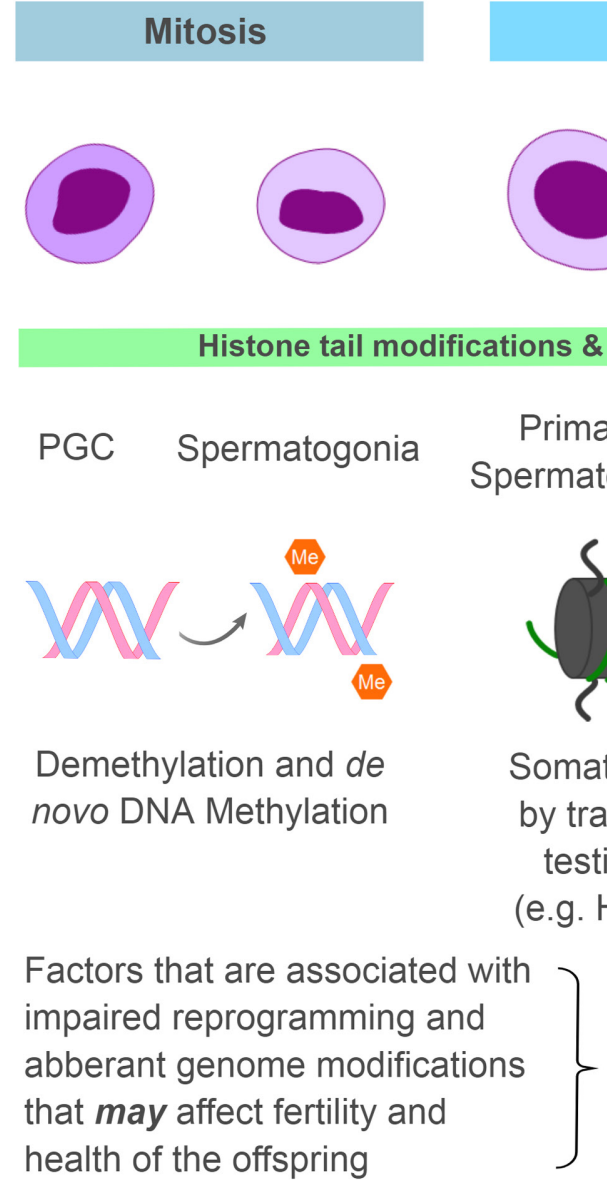

Meiosis

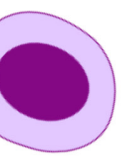

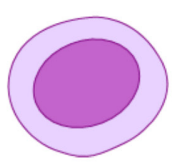

\section{Post-meiotic differentiation}
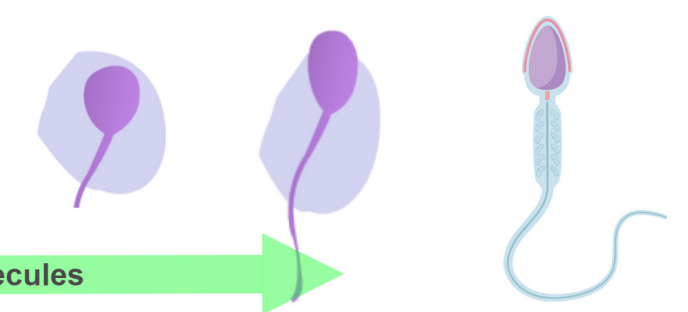

Spermatozoon $\begin{array}{cc}\text { Round } & \text { Elongated } \\ \text { Spermatid } & \text { Spermatid }\end{array}$

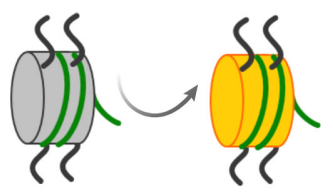

Histone-to-protamine transition

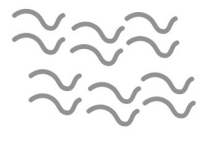

Storage of differnetially expressed RNAs testis-specific variants .g. H3.3, H3t, hTSH2B)

- Environmental toxins e.g. paints, hydrocarbons, pesticides (Spermatogenesis impairing)

\section{- Diet and smoking • Sperm cryopreservation}

- Estrogen receptor agonists

Figure 1 Reconfiguration of the sperm epigenome during spermatogenesis. The genome of PGCs is demethylated prenatally during the colonisation of the genital ridge with migratory PGCs. Establishment of global DNA methylation occurs in mitotically arrested prospermatogonia and is completed prior to birth (Li et al. 2004, Stewart et al. 2016). De novo DNA methylation in prospermatogonia coincides with an early redistribution of the histone tail marks H3K4me2/3 and H3K36me3 (Singh et al. 2013, Morselli et al. 2015). Other histone tail modifications, such as acetylation of histone 4 lysine residues, occur later in elongating spermatids during spermiogenesis (Oliva \& Mezquita 1982, Lahn et al. 2002, Awe \& Renkawitz-Pohl 2010). Testis-specific histone variants are expressed throughout spermatogenesis until the elongated spermatid stage when they are, along with the majority of the core histones, sequentially replaced by transitionary proteins prior to histone-to-protamine transition and hyper-compaction of the chromatin (Zalensky et al. 2002, Bao \& Bedford 2016, Ueda et al. 2017). RNA molecules that are expressed throughout spermatogenesis and stored in mature spermatozoa may reflect sperm maturation, fertility potential and the paternal contribution to the development of the offspring (Meikar et al. 2011, Godia et al. 2018). An example of some of the factors that have been shown to be associated with aberrant reprogramming during spermatogenesis (e.g. diet and smoking), discussed in this review, are highlighted. This figure was prepared using the Biomedical PPT toolkit suite (www.motifolio.com) and Biorender (https://biorender.io/). PGCs, 
(PGCs) and the second following fertilisation in the pre-implantation embryo (Prokopuk et al. 2015). These events have been mostly characterised using the murine model and, although epigenetic profiles have been assessed in spermatozoa and embryos of other species (Dean et al. 2001, Beaujean et al. 2004, Deshmukh et al. 2011, O'Doherty et al. 2012, 2015, Guo et al. 2014b), detailed comparative studies are still lacking. Firstly, during proliferation and migration of PGCs from the epiblast to colonisation of the genital ridge ( E6.5E13.5), the PGC genome is demethylated in a biphasic manner that results in their genomes displaying very low levels of DNA methylation (Messerschmidt et al. 2014). From here, PGCs are divergently remethylated in males and females in a germ cell-specific fashion (Sasaki \& Matsui 2008, Seisenberger et al. 2012). Male germ cells gain as much as 50\% global methylation by E16.5 and are almost completely methylated at birth. In contrast, remethylation in the female germline occurs after birth, during the oocyte growth phase $\left(\mathrm{O}^{\prime}\right.$ Doherty et al. 2012, Tomizawa et al. 2012). Secondly, following fertilisation, male pronuclei are actively and rapidly demethylated in the zygote while the maternal genome is passively demethylated in a replication-dependent manner during cleavage (Lees-Murdock \& Walsh 2008). Until recently, it was widely accepted that the maternal genome and paternal genome were not actively demethylated or passively demethylated, respectively. It should be noted, however, that active and passive demethylation do not occur exclusively on the paternal and maternal genomes, as it has been demonstrated that both genomes undergo widespread active and passive demethylation in the zygote prior to the first mitotic division (Gkountela \& Clark 2014, Guo et al. 2014a).

These periods of reprogramming occur during crucial developmental time points and represent windows of susceptibility for epigenetic errors to be introduced, that may impact fertility and embryonic competence. Over four decades ago, it was reported that a Fathers occupation, and potential exposure to (spermatogenesis impairing) environmental toxins, was associated with carcinogenic defects being transmitted to their children (Fabia \& Thuy 1974). Since then, a number of other studies have shown links between paternal exposure to environmental toxins (e.g. paints, hydrocarbons, pesticides) and offspring health; reviewed in (Soubry etal. 2014). Given the continuous cycles of mitosis and meiosis that occur during spermatogenesis in adult males, the chances of accumulating environmentally induced epigenetic errors during this protracted period of replication and cell division are much greater in males than in females (Messerschmidt et al. 2014).

\section{DNA methylation}

As mentioned earlier, DNA methylation is the most widely investigated epigenetic mark. This epigenetic modification is essential for male and female gametogenesis and mammalian development (Okano et al. 1999, Bourc'his et al. 2001, Kaneda et al. 2004). In the mammalian genome, DNA methylation mostly occurs on the fifth position of cytosine bases in the context of cytosine followed by guanine (CpG dinucleotides): this is referred to as 5-methylcytosine (5mC) (Yoder et al. 1997). It can also occur to a much lesser extent at cytosine bases in a non-CpG context (Jang et al. 2017). Additionally, $5 \mathrm{mC}$ can be oxidised by members of the ten-eleven translocation family of proteins to form 5-hydroxymethylcytosine (5hmC), 5-formylcytosine and 5-carboxylcytosine (Ito et al. 2011, Wu \& Zhang 2014, Neri et al. 2016). These intermediary modifications are much less studied compared to $5 \mathrm{mC}$ or $5 \mathrm{hmC}$ and are yet to be characterised during male gametogenesis.

Aberrations in sperm DNA methylation have also been shown to be associated with abnormalities in semen parameters (low sperm count, decreased volume of semen, reduced progressive motility, high percentage of immotile sperm lowered sperm vitality) of subfertile males that were trying to conceive for at least 10 years (Laqqan et al. 2017a). The authors of this study identified that DNA methylation was consistently different at a small number of CpGs between proven fertile males and subfertile case subjects, using Infinium Human Methylation $450 \mathrm{~K}$ BeadChip arrays, validating previous findings using local deep bisulfite sequencing (Gries et al. 2013). This study builds on earlier investigations, and recent studies by Nasri et al. (2017) and Kobayashi et al. (2017), showing that aberrant methylation, particularly at imprinted loci, is associated with poor-quality sperm (Marques et al. 2004, 2008, Kobayashi et al. 2007, Poplinski et al. 2010, Pacheco et al. 2011, Laurentino et al. 2015). However, the methylation differences in Laqqan et al. study were very small and restricted to a small number of CpGs; therefore, whether these differences are related to the subfertile phenotype remains to be fully determined. In a previous study using the same $450 \mathrm{~K}$ DNA methylation array, Urdinguio et al. revealed that DNA methylation patterns in the male partners of couples with UMI were measurably different at specific loci and Alu Yb8 repetitive elements (Urdinguio et al. 2015). Given that no abnormalities in semen parameters are distinguishable between UMI patients and fertile control patients, and that female factor infertility was ruled out, this study provides encouraging evidence to show that aberrant sperm DNA methylation may be associated with fertility impairment in couples with UMI. This is further supported by a study by Aston and colleagues showing that, in similar cohorts of patients, sperm DNA methylation may be used to predict fertility and potentially predictive of embryo quality during IVF (Aston et al. 2015). 
It has been reported that smoking has a strong correlation with CpG methylation and sperm count, morphology and motility (Laqqan et al. 2017b). The authors of this study also identified that smoking is associated with changes in sperm DNA methylation patterns, specifically at $\mathrm{CpGs}$ located in regions related to MAPK8IP and TKR genes. A link between smoking, male fertility and methylation at imprinted loci has been highlighted in a study by Dong et al. (2016). In this study, they revealed that hypomethylation of the H19 imprint control region (ICR) and hypermethylation of the SNRPN-ICR were associated with infertility and that the risk was potentiated by smoking. In addition to smoking, alcohol consumption has been shown to be associated with DNA methylation at regulatory regions of the imprinted gene, $\mathbf{H 1 9}$, in spermatozoa of humans and mice; however, the impact of alcohol-induced alteration to DNA methylation on fertility remains to be determined (Ouko et al. 2009, Stouder et al. 2011, Lim \& Song 2012).

The effect of paternal diet on sperm quality, offspring health and epigenetics has been discussed previously (Schagdarsurengin \& Steger 2016). In an early study, it was demonstrated that offspring from male mice fed a lowprotein diet exhibited differential expression of key lipid and cholesterol biosynthesis-related genes in the liver that may be related to altered DNA methylation patterns inherited through the male germline (Carone et al. 2010). In a similar study, differential methylation was observed at genes implicated in development, chronic diseases, diabetes, autism and schizophrenia in sperm isolated from mice fed a folate-deficient diet, providing evidence for a possible link between diet, the sperm methylome and offspring health (Lambrot et al. 2013). However, it was reported in a subsequent study from Rando and colleagues that, although paternal diet has an effect on offspring phenotype, no consistent effects of diet on the sperm methylome are observable and that variation in offspring DNA methylation is due to genetic and epigenetic variations (Rando \& Simmons 2015, Shea et al. 2015, Whitelaw 2015). Although the precise epigenetic mechanism/s of how the paternal diet can affect fertility and offspring health remain to be fully unravelled, the importance of the paternal (and maternal) diet on fertility should not be disregarded and needs to be investigated further.

\section{Chromatin structure and modifications}

During the finally stages of male gametogenesis (spermiogenesis), motile spermatozoa develop from haploid round spermatids (Bao \& Bedford 2016). The chromatin undergoes a dramatic reconfiguration during this time, when the vast majority (90-95\%) of nucleosomal core histones $(\mathrm{H} 2 \mathrm{~A}, \mathrm{H} 2 \mathrm{~B}, \mathrm{H} 3$ and $\mathrm{H} 4)$ are first replaced by transitionary proteins and then by protamines (Balhorn 1982, Meistrich et al. 2003,
Eirin-Lopez et al. 2006, Rathke et al. 2014). This process, known as histone-to-protamine transition, facilitates a tight packaging of sperm DNA enabling condensation of sperm heads and protection of DNA from damage and mutagenesis (Ward \& Coffey 1991, Rathke et al. 2014). The ratio of remaining nuclear histones to protamines has been shown to play a role in male fertility (Zhang et al. 2006). Findings from this study suggested that infertile men possess a higher proportion of spermatozoa with an increased histone-to-protamine ratio, compared to fertile controls. Histone-to-protamine transition and links with fertility have also been reported elsewhere (Carrell \& Liu 2001, Aoki et al. 2006, Carrell et al. 2007). These studies showed that altered expression of protamine, protamine 1 and protamine 2 are related to diminished spermatogenesis and fertilisation capacity. In addition, cryopreservation, a routinely used process for sperm storage in fertility clinics, has been shown to impact chromatin integrity (Fortunato et al. 2013). The authors of this study reported that cryopreservation influenced chromatin decondensation and may lead to sperm chromatin cryoinjury.

The small proportion of histones (5-10\%) that are retained during histone-to-protamine transition and the post-translational modification of these remaining histones and their tails is an expanding area of biological research (Carrell \& Hammoud 2010, Krejci et al. 2015). Retained histones are modifiable and thought to occur at specific genomic loci that are involved with regulating transcription following fertilisation (Hammoud et al. 2009, Miller et al. 2010). However, the number of studies investigating the relationship between chromatin structure in sperm and fertility remains substantially lower, relative to studies involving DNA methylation or abundance of RNA molecules (discussed later). One potential hurdle may be that pinpointing histone modifications that are directly associated with fertility may be difficult due to the plethora of post-translational modifications (e.g. acetylation, methylation, SUMOylation, phosphorylation) that can be present on the various histone isoforms (Luense et al. 2016). However, studies have shown links between fertility and chromatin structure and are discussed below.

Several recent studies investigating the relationship between chromatin structure and male fertility have been carried out using the bovine model. An early study evaluated the differences in bull fertility, histone retention and expression of a histone variant $(\mathrm{H} 3.3)$ and two core histones ( $\mathrm{H} 2 \mathrm{~B}$ and $\mathrm{H} 4)$ using immunoblotting, immunocytochemistry and staining techniques (de Oliveira et al. 2013). Although no differences were detected for $\mathrm{H} 3.3, \mathrm{H} 2 \mathrm{~B}$ or $\mathrm{H} 4$ between sperm from the low-fertility (LF) group and the high-fertility (HF) group, there were differences in chromatin condensation between the groups that were associated with in vivo bull fertility. Interestingly, using transgenic mice carrying null mutations at two genes encoding the histone variant 
H3.3, Tang and colleagues revealed that H3.3 is heavily involved in viability and male fertility (Tang et al. 2015). Using immunocytochemistry and flow cytometry techniques, it has been shown that acetylation and methylation of sperm histone 3 lysine 27 (H3K27ac and H3K27me3) are associated with bull fertility (Kutchy et al. 2018). Furthermore, flow cytometry, immunofluorescence and western blotting have been used to demonstrate that expression of the testis-specific histone variant $2 \mathrm{~B}(\mathrm{TH} 2 \mathrm{~B})$ in sperm isolated from bulls with contrasting fertility scores can be potentially used to evaluate semen quality and male fertility (Kutchy et al. 2017). In another in vitro study comparing $\mathrm{HF}$ and LF bulls, Castro and colleagues assessed the potential contribution of chromatin integrity to fertility using three separate approaches to evaluate chromatin deficiency (CMA3), chromatin stability (SCSA; AO+) and DNA fragmentation (COMET assay) (Castro et al. 2018). Although differences in chromatin deficiency were observed between the HF and LF groups, the authors concluded that protamine deficiency in bovine spermatozoa may not have a strong biological impact on in vitro fertility.

Using a more targeted approach with a custom ChIPon-chip array, Verma et al. investigated di-methylated H3K4 (H3K4me2) and tri-methylated H3K27 (H3K27me3) in spermatozoa of water buffalo bulls (Bubalus bubalis) identified as having wide differences in fertility (Verma et al. 2015). For H3K4me2 and H3K24me3, the authors identified 84 and 80 genes, respectively, that were differentially enriched between mature sperm from high and sub-fertile bulls. Gene ontology analysis of these differentially marked genes revealed enrichment for processes such as germ cell development, spermatogenesis and embryonic development-demonstrating that appropriate chromatin configuration at functionally relevant genes is related to bull fertility. Similarly, it has recently been shown that epigenetic marks in the sperm of Xenopus laevis, a model organism for developmental biology research, regulate embryonic gene expression (Teperek et al. 2016). Specifically, this work showed important regulatory roles for loss of methylation of histone $\mathrm{H} 3$ on lysine $4(\mathrm{H} 3 \mathrm{~K} 4)$ and retention of methylation of histone $\mathrm{H} 3$ on lysine 27 (H3K27) and demonstrated that epigenetic cues delivered by the sperm are required for correct embryonic gene expression. Work by Öst and colleagues, using the model organism Drosophila, provided a link between paternal sugar intake, H3K9/ K27me3-dependent reprogramming of metabolic genes and offspring adiposity (Ost et al. 2014). In humans, acetylation of histone $\mathrm{H} 4$ at lysine 12 (H4K12ac) has been implicated at developmentally important gene promoters in subfertile men (Vieweg et al. 2015).

Work by Dumasia and colleagues, looking at the roles of oestrogen and the oestrogen receptors (ESRs) during rat spermatogenesis, has shown that ESR are involved with spermatogenesis and fertility (Dumasia et al. 2015, 2016, Kumar et al. 2017); oestrogen signalling regulates DNA methylation (Dumasia et al. 2017a) and that treating adult rats with selective ESR agonists resulted in altered chromatin modifications in the testis (Dumasia et al. 2017b). More specifically, they found that ESR agonist treatment caused increased histone retention, protamine deficiencies, and altered levels of histone modifications that correspond with active and repressed chromatin states, and altered heterochromatin marks (Dumasia et al. 2017b). In another study investigating the impact of oestrogens in the environment, Filby et al. analysed Pimephales promelas, a model fish species, after exposure to differing concentrations of oestrogen as a single chemical and as part of an oestrogenic effluent from waste water treatment work (WwTW) (Filby et al. 2007). They revealed an association between oestrogens in the environment and some adverse and sex-related health effects observed in the fish including genotoxic damage, modulated immune function, and altered metabolism, in addition to endocrine disruption (Filby et al. 2007). Future studies investigating the impact of environmental oestrogens will allow us to determine how they affect chromatin remodelling during spermatogenesis and if they negatively impact male fertility.

\section{Sperm-borne coding and non-coding RNA molecules}

Until recently the presence of RNA in sperm was largely thought to be due to carryover or contamination with non-sperm cells (discussed in O'Doherty \& McGettigan 2014). The presence and characterisation of RNA molecules in sperm has been confirmed and greatly facilitated in recent years through technological advances in sequencing platforms and the focus has now shifted to elucidating their function. Although transcriptionally quiescent, sperm have been shown to contain a wide variety of RNA molecules, both coding and non-coding, reported to be required for spermatogenesis, early development and epigenetic inheritance (Schuster et al. 2016). Transcriptomic analysis of sperm isolated from men of known fertility, idiopathic infertility (normozoospermic patients), and asthenozoospermia (reduced motility) has identified different RNA profiles between the patient cohorts, highlighting the potential importance of these molecules in male fertility (Bansal et al. 2015).

It has been reported in humans that as little as $2 \%$ of transcriptional output is translated into protein, thus the remaining 98\% is non-coding (Mattick 2001). The inclusion of ncRNA as epigenetic regulators of gene function remains somewhat divisive and evokes discussions on whether it is appropriate to define them as such. The focus of this review is not to determine whether or not ncRNAs should be included under the 
epigenetic umbrella. Therefore, we will take the wider view that they are involved in epigenetic regulation and will report the most recent findings linking them with male infertility. Isolation of sperm RNAs remains methodologically challenging due to their very low abundancies and affinity of certain RNAs to chromatin (Goodrich et al. 2007, 2013). Nevertheless, many investigations, summarised hereafter, have reported associations between sperm-borne RNA molecules and fertility and shown that they have key roles in subsequent embryonic development.

A 2015 study suggested that analysing sperm RNA elements (SREs) could be an efficient predictor of effective fertility treatments on an individual level (Jodar et al. 2015). This study revealed that idiopathic infertile couples who had an incomplete set of necessary SREs had a significantly reduced probability of achieving a live birth by intrauterine insemination (IUI) or timed intercourse (TIC) from 73 to $27 \%$. When using assisted reproductive technologies (ART), such as IVF or ICSI, the absence of SREs did not seem to be critical. Furthermore, this study showed that the infertility of idiopathic infertile couples without a complete set of SREs is most likely due to a male component. While the infertility of couples that failed to achieve a live birth, but have a complete set of SREs, could be due to female factor infertility.

Since the discovery of epigenetic reprogramming during gametogenesis and embryogenesis (Reik et al. 2001), and recent studies showing that environmentally induced DNA methylation alterations in the F1 generation are not maintained in the F2 generation (Radford et al. 2014) and that sperm methylation errors are corrected by reprogramming (de Waal et al. 2012, Iqbal et al. 2015), epigenetic researchers have shifted their focus to other molecules and mechanisms that have been proposed to play a role in maintaining transgenerational transfer of acquired traits, such as sperm RNAs and sperm RNA modifications (Chen et al. 2016). The first major piece of evidence supporting a role for sperm RNAs in the transgenerational inheritance of acquired traits came from a 2014 study which demonstrated that by injecting total sperm RNAs from mice that were exposed to mentally stressful conditions into normal zygotes, behavioural patterns and alterations in metabolism that were observed in the father can be recapitulated in the offspring, and maintained through subsequent generations (Chen et al. 2016). Subsequent studies showed that mice who were fed a high-fat diet (HFD) or high-fat-high-sugar diet also contained sperm RNAs that, when injected into normal zygotes, would produce offspring with similar paternal metabolic disorders (Chen et al. 2016). These studies have led many researchers to question which RNAs are potentially responsible for transmitting the paternal phenotypes. Recent evidence has turned researchers' attentions to sperm tsRNAs and miRNAs, which are up regulated in mature sperm after HFD, low-protein diets or after other environmental exposures (Chen et al. 2016).

The ncRNA transcriptome can be broadly divided into two main groups based on their length. The first group is comprised of short ncRNAs ranging between 20 and 30 nucleotides and the second group is made up of IncRNA transcripts that are $>200$ nucleotides in length. The role of these two groups of RNAs in male factor infertility is discussed below.

\section{Short non-coding RNAs}

Short ncRNAs have been investigated extensively during the past decade (Huang et al. 2013). Two short ncRNA classes, sperm piRNA and microRNA (miRNA), which play an essential role in spermatogenesis, have been implicated in male fertility disorders (Carmell et al. 2007, Houwing et al. 2007, Das et al. 2008). Capra et al. recently investigated piRNAs and miRNAs derived from high motile and low motile cryopreserved bovine spermatozoa populations, through small RNA sequencing, and found that a number of miRNAs were differentially expressed in the two populations (Capra et al. 2017). Moreover, they found that these miRNAs targeted genes involved in apoptosis, mitochondrial membrane integrity and spermatogenesis alteration, indicating a possible role in bull fertility. In a study by Pantano et al., small RNA sequencing revealed an abundance of piRNAs derived from pseudogenes (Pantano et al. 2015). The authors proposed that these pseudogene-derived piRNAs may regulate their parent gene expression during sperm development and therefore may be required for fertility. Analysis of spermatozoa from normozoospermic fertile and normozoospermic infertile patients, using the TaqMan Array Human MicroRNA, has revealed that normozoospermic fertile and infertile individuals convey distinct miRNA cargos that may have implications in male reproductive performance (SalasHuetos et al. 2016).

Recent studies have shown that the injection of specific subsets of miRNAs into normal zygotes can reproduce paternal phenotypes which can be followed into subsequent generations, suggesting that these miRNA can induce changes that are maintained in the germline. tsRNAs, which are derived from the $5^{\prime}$ end of tRNAs, have also been shown to be involved in epigenetic inheritance of acquired traits. By injecting sperm tsRNA from mice that were on a HFD into normal zygotes, researches have shown that metabolic disorders observed in the father can be recapitulated in the offspring (Chen et al. 2016).

In non-mammalian species, the recently discovered phase small-interfering RNAs (phasiRNA), that bear similarities to mammalian piRNAs (Zhai et al. 2015), have been shown to be important for male meiosis and fertility in plants (Dukowic-Schulze et al. 2016, Fan et al. 2016). A study using photoperiod-sensitive 
male sterility (PSMS) rice (Oryza sativa L.) demonstrated the potential biological importance of (phasiRNA), which are an emerging class of 21- or 24-nt small RNAs generated from precursor RNA. This study showed that accumulation of a $21 \mathrm{nt}$ PMS1T-phasiRNA eventually caused male sterility in the rice, although further studies are needed to elucidate the mechanistic pathway involved (Fan et al. 2016).

\section{Long non-coding RNAs}

IncRNAs have gained considerable attention in recent years. They are, generally, polyadenylated non-coding RNA molecules that are RNA Polymerase II transcribed. Although classified as non-coding, it should be noted that a number of IncRNAs have been shown to harbour short open reading frames (sORFs) that can be translated into short peptides (Rohrig et al. 2002, Galindo et al. 2007, Kondo et al. 2007, 2010, Magny et al. 2013, Anderson et al. 2015). IncRNAs have been shown to possess a variety of functions such as transportation of mRNA from the nucleus (Chen \& Carmichael 2009), acting as competing endogenous RNAs for miRNAs (Cheng \& Lin 2013) and decoys for DNA-binding proteins (Kino et al. 2010). Some well characterised IncRNAs are involved in regulating imprinted gene expression and $\mathrm{X}$ chromosome inactivation and include Xist (Brockdorff et al. 1992), H19 (Brannan et al. 1990) and AIRN (Sleutels et al. 2002). For an in-depth review on the evolution, genomic contexts, biological functions, and mechanisms of action of IncRNAs (Kung et al. 2013). IncRNAs have pivotal roles during animal sperm development, for a comprehensive reviews on IncRNA during spermatogenesis (Luk et al. 2014, Zhang et al. 2016).

It has been reported that type 1 and type 2 diabetes mellitus can negatively impact fertility (Singh et al. 2014, Wiebe et al. 2014) and there is a great amount of data indicating that IncRNAs are involved in diabetes mellitus, reviewed in (He et al. 2017). A large number of IncRNAs (and mRNAs) are differentially expressed in sperm isolated from diabetic and nondiabetic mice models (Jiang et al. 2016), therefore it is possible that some of these IncRNAs are related to diabetes-related male infertility - however larger studies are needed to confirm or rule this possibility out. IncRNAs have also been shown to play a role in sperm motility (Liu et al. 2017). Using Beijingyou cocks with divergent sperm motility scores, Liu and colleagues identified several IncRNAs that were differentially expressed in the testis between animals with high and low sperm motility. Although this study provides some novel data linking IncRNAs to sperm motility (and potentially fertility), analysis of IncRNA in the high and low motility sperm, and the fertility of said sperm, would aid in the identification of motilityassociated IncRNAs.
Although having important roles during spermatogenesis and potentially being important for male fertility, some IncRNAs have been shown to be indispensable for fertility. Despite being enriched in the sperm nucleus, transgenic mice carrying homozygous null mutations for the IncRNA, Malat1, have no identifiable defeats in fertility (Zhang et al. 2012, Johnson et al. 2015). Similarly, knockout of the testisspecific IncRNA, Tsx, results in viable fertile offspring (Anguera et al. 2011). These studies show that although IncRNAs can be important for germ cell development they may not be required for fertility; and thus highlight the requirement for further studies aimed at identifying the role of IncRNAs in male fertility.

\section{Modification of RNA}

In addition to the involvement of a variety of RNA molecules in male fertility, modifications to RNA itself have also been implicated in fertility. Although there are in excess of 140 modified RNA nucleotide variants, one RNA modification that is getting a lot of attention recently is $\mathrm{N}^{6}$-methyladenine $\left(\mathrm{m}^{6} \mathrm{~A}\right)$, in which an adenine base is methylated at the $6^{\prime}$ position (Fu et al. 2014). $\mathrm{m}^{6} \mathrm{~A}$ is the most abundant mRNA/IncRNA modification discovered thus far, and is the only modification that has exhibited characteristics of epigenetic regulation including readers, writers and erasers (Dominissini et al. 2012, Meyer \& Jaffrey 2014, Liu \& Pan 2015). $m^{6}$ A has been implicated at virtually every level of mRNA regulation including pre-mRNA splicing, mRNA export, and stability, and translation of mRNA (Lin et al. 2017). Due to $\mathrm{m}^{6} \mathrm{~A}^{\prime} \mathrm{s}$ extensive involvement in many biological processes, it has been associated with cancer progression (Batista et al. 2014, Geula et al. 2015) and many diseases including obesity and diabetes (Zeggini et al. 2007, Jia et al. 2011).

Work by Yang and colleagues has identified an association between levels of $\mathrm{m}^{6} \mathrm{~A}$ in human sperm and fertility (Yang et al. 2016). The authors revealed that individuals with asthenozoospermia have increased levels of $\mathrm{m}^{6} \mathrm{~A}$ compared to controls and suggested that increased levels of spermatozoal $\mathrm{m}^{6} \mathrm{~A}$ is a potential risk factor for decreased sperm motility (Yang et al. 2016). The $\mathrm{m}^{6} \mathrm{~A}$ modification has also been shown to be functionally vital for the survival of cells in culture in a study demonstrating that siRNA knockdown of METTL3, the methyltransferase known to be involved in $\mathrm{m}^{6} \mathrm{~A}$ methylation, results in apoptosis (Lin et al. 2016). Another study showed that inactivation of either Mett/3 or Mett/14 in a male germ-cell specific manner resulted in a lack of $\mathrm{m}^{6} \mathrm{~A}$, which results in translational dysregulation and subsequently, a depletion of spermatagonial stem cells (SSC), although normal spermatogenesis was observed (Lin et al. 2017). However, this study also showed that double deletion of Mett/3 and Mett/14 results in impaired spermiogenesis due to translational dysregulation of 
factors that are key to spermatogenesis (Lin et al. 2017). $\mathrm{m}^{6} \mathrm{~A}$ has been shown to be dynamically regulated at different developmental stages during spermatogenesis, with $\mathrm{m}^{6} \mathrm{~A}$ enrichment occurring in pachytene/diplotene spermatocytes and round spermatids (Lin et al. 2017). These studies suggest that $\mathrm{mRNA} \mathrm{m}^{6} \mathrm{~A}$ modifications are critical to the temporal regulation of translation during spermatogenesis by marking genes that are key factors during spermatogenesis, stabilising those transcripts, increasing their translation, and preventing translation of genes that would be deleterious by erasing the $\mathrm{m}^{6} \mathrm{~A}$ modification.

Mutation of a gene that is involved in the regulation of RNA modifications has also been shown to potentially influence male fertility (Zheng et al. 2013). A mutation in the gene that encodes ALKBH5, an $\mathrm{m}^{6} \mathrm{~A}$ demethylase, causes increased levels of $m^{6} A$, which also affects the export and metabolism of mRNA, and results in aberrant spermatogenesis, low sperm count, poor quality sperm and impaired fertility (Zheng et al. 2013). ALKBH5deficient mice have been shown to have decreased testes size (Tang et al. 2018) and a reduced breeding success rate (Zheng et al. 2013), which has steered researchers focus to ALKBH5's role in spermatogenesis. Subsequent studies by an independent group have shown that $\mathrm{ALKBH} 5$ is required for late meiotic and haploid phases of spermatogenesis (Tang et al. 2018). To study $\mathrm{m}^{6} \mathrm{~A}$ modification in mRNA and IncRNA researchers use a method referred to as $\mathrm{m}^{6} \mathrm{~A}$-seq or MeRIP-seq in which an $\mathrm{m}^{6} \mathrm{~A}$ antibody is used to immunoprecipitate RNAs with the $\mathrm{m}^{6} \mathrm{~A}$ modification, followed by high-throughput sequencing (Tang et al. 2018). Due to the advancement in deep sequencing technologies, researchers have been able to map $\mathrm{m}^{6} \mathrm{~A}$ modification using this method at a single nucleotide resolution and have found these modification to be enriched around stop codons and internal exons (Liebers et al. 2014, Linder et al. 2015). These advancements will help researchers to discovery novel roles of $\mathrm{m}^{6} \mathrm{~A}$ modification and other RNA modifications alike.

\section{Concluding remarks}

Deciphering the underlying cause of male infertility, and determining the key molecular players, still remains a major challenge in reproductive medicine. This review highlights that there are many epigenetic factors involved with multiple layers of gene regulation at multiple genomic loci, related to sperm function and potentially important for fertility. As with any field of biological research, technical and biological limitations need to be carefully considered, the utility of sperm epigenetics and potential hurdles have been discussed in-depth recently by Jenkins and colleagues (Jenkins et al. 2017). However, carefully designed future studies investigating epigenetic modifications of the sperm genome and the vast suite of sperm-borne RNA molecules, and their modifications, are warranted and will help to shed more light on their involvement (cause or correlation) with male infertility and help with the development of new diagnostics and possibly therapeutics. Male infertility research will greatly benefit from studies using larger sample sizes that integrate multiple epigenomic analyses (integromics). This will help in the identification of robust epigenetic markers of fertility/infertility.

The majority of the studies examining the contribution of epigenetic processes to infertility discussed in this review have used samples consisting of large numbers of sperm. Given that sperm are one of the most diverse cell types (Ramon et al. 2014) and that sperm have been reported to be epigenetically heterogeneous (Laurentino et al. 2016), future investigations using highthroughput single cell epigenomics will be important to help determine whether aberrant infertility-related epigenetic marks are present in all spermatozoa of the ejaculate. Finally, advising couples suffering from UMI, and males in general, on known risk factors such as smoking (Dong et al. 2016, Laqqan et al. 2017b), obesity (Katib 2015, Craig et al. 2017) and alcohol consumption (Ouko et al. 2009, Lim \& Song 2012) may help to reduce infertility-related epigenetic aberrancies in sperm and go some way on the long road to understanding and potentially treating male factor infertility.

\section{Declaration of interest}

The authors declare that there is no conflict of interest that could be perceived as prejudicing the impartiality of this review.

\section{Funding}

This research did not receive any specific grant from any funding agency in the public, commercial or not-for-profit sector.

\section{References}

Anderson DM, Anderson KM, Chang CL, Makarewich CA, Nelson BR, McAnally JR, Kasaragod P, Shelton JM, Liou J, Bassel-Duby R et al. 2015 A micropeptide encoded by a putative long noncoding RNA regulates muscle performance. Cell 160 595-606. (https://doi.org/10.1016/j. cell.2015.01.009)

Anguera MC, Ma W, Clift D, Namekawa S, Kelleher RJ 3rd \& Lee JT 2011 Tsx produces a long noncoding RNA and has general functions in the germline, stem cells, and brain. PLoS Genetics 7 e1002248. (https://doi. org/10.1371/journal.pgen.1002248)

Aoki VW, Liu L, Jones KP, Hatasaka HH, Gibson M, Peterson CM \& Carrell DT 2006 Sperm protamine 1/protamine 2 ratios are related to in vitro fertilization pregnancy rates and predictive of fertilization ability. Fertility and Sterility 86 1408-1415. (https://doi.org/10.1016/j. fertnstert.2006.04.024)

Aston KI, Uren PJ, Jenkins TG, Horsager A, Cairns BR, Smith AD \& Carrell DT 2015 Aberrant sperm DNA methylation predicts male fertility status and embryo quality. Fertility and Sterility 104 1388.e1381-1397. e1385. (https://doi.org/10.1016/j.fertnstert.2015.08.019)

AweS \& Renkawitz-PohIR2010 Histone H4 acetylation is essential toproceed from a histone- to a protamine-based chromatin structure in spermatid nuclei of Drosophila melanogaster. Systems Biology in Reproductive Medicine 56 44-61. (https://doi.org/10.3109/19396360903490790) 
Balhorn R 1982 A model for the structure of chromatin in mammalian sperm. Journal of Cell Biology 93 298-305. (https://doi.org/10.1083/ jcb.93.2.298)

Bansal SK, Gupta N, Sankhwar SN \& Rajender S 2015 Differential genes expression between fertile and infertile spermatozoa revealed by transcriptome analysis. PLOS ONE 10 e0127007. (https://doi. org/10.1371/journal.pone.0127007)

Bao J \& Bedford MT 2016 Epigenetic regulation of the histone-to-protamine transition during spermiogenesis. Reproduction 151 R55-R70. (https:// doi.org/10.1530/REP-15-0562)

Batista PJ, Molinie B, Wang J, Qu K, Zhang J, Li L, Bouley DM, Lujan E, Haddad B, Daneshvar K et al. 2014 m(6)A RNA modification controls cell fate transition in mammalian embryonic stem cells. Cell Stem Cell 15 707-719. (https://doi.org/10.1016/j.stem.2014.09.019)

Beaujean N, Taylor JE, McGarry M, Gardner JO, Wilmut I, Loi P, Ptak G, Galli C, Lazzari G, Bird A et al. 2004 The effect of interspecific oocytes on demethylation of sperm DNA. PNAS 101 7636-7640. (https://doi. org/10.1073/pnas.0400730101)

Bourc'his D, Xu GL, Lin CS, Bollman B \& Bestor TH 2001 Dnmt3L and the establishment of maternal genomic imprints. Science 294 2536-2539. (https://doi.org/10.1126/science.1065848)

Brannan CI, Dees EC, Ingram RS \& Tilghman SM 1990 The product of the $\mathrm{H} 19$ gene may function as an RNA. Molecular and Cellular Biology 10 28-36. (https://doi.org/10.1128/MCB.10.1.28)

Brockdorff N, Ashworth A, Kay GF, McCabe VM, Norris DP, Cooper PJ, Swift S \& Rastan S 1992 The product of the mouse Xist gene is a 15 $\mathrm{kb}$ inactive $\mathrm{X}$-specific transcript containing no conserved ORF and located in the nucleus. Cell 71 515-526. (https://doi.org/10.1016/0092 8674(92)90519-I)

Capra E, Turri F, Lazzari B, Cremonesi P, Gliozzi TM, Fojadelli I, Stella A \& Pizzi F 2017 Small RNA sequencing of cryopreserved semen from single bull revealed altered miRNAs and piRNAs expression between high- and low-motile sperm populations. BMC Genomics 18 14. (https:// doi.org/10.1186/s12864-016-3394-7)

Carmell MA, Girard A, van de Kant HJ, Bourc'his D, Bestor TH, de Rooij DG \& Hannon GJ 2007 MIWI2 is essential for spermatogenesis and repression of transposons in the mouse male germline. Developmental Cell 12 503-514. (https://doi.org/10.1016/j.devcel.2007.03.001)

Carone BR, Fauquier L, Habib N, Shea JM, Hart CE, Li R, Bock C, Li C, Gu H, Zamore PD et al. 2010 Paternally induced transgenerational environmental reprogramming of metabolic gene expression in mammals. Cell 143 1084-1096. (https://doi.org/10.1016/j.cell.2010.12.008)

Carrell DT \& Hammoud SS 2010 The human sperm epigenome and its potential role in embryonic development. Molecular Human Reproduction 16 37-47. (https://doi.org/10.1093/molehr/gap090)

Carrell DT \& Liu L 2001 Altered protamine 2 expression is uncommon in donors of known fertility, but common among men with poor fertilizing capacity, and may reflect other abnormalities of spermiogenesis. Journal of Andrology 22 604-610. (https://doi.org/10.1002/j.1939-4640.2001. tb02220.x)

Carrell DT, Emery BR \& Hammoud S 2007 Altered protamine expression and diminished spermatogenesis: what is the link? Human Reproduction Update 13 313-327. (https://doi.org/10.1093/humupd/dml057)

Castro LS, Siqueira AFP, Hamilton TRS, Mendes CM, Visintin JA \& Assumpcao M 2018 Effect of bovine sperm chromatin integrity evaluated using three different methods on in vitro fertility. Theriogenology $\mathbf{1 0 7}$ 142-148. (https://doi.org/10.1016/j.theriogenology.2017.11.006)

Chen LL \& Carmichael GG 2009 Altered nuclear retention of mRNAs containing inverted repeats in human embryonic stem cells: functional role of a nuclear noncoding RNA. Molecular Cell 35 467-478. (https:// doi.org/10.1016/j.molcel.2009.06.027)

Chen Q, Yan W \& Duan E 2016 Epigenetic inheritance of acquired traits through sperm RNAs and sperm RNA modifications. Nature Reviews Genetics 17 733-743. (https://doi.org/10.1038/nrg.2016.106)

Cheng EC \& Lin H 2013 Repressing the repressor: a lincRNA as a MicroRNA sponge in embryonic stem cell self-renewal. Developmental Cell 25 1-2. (https://doi.org/10.1016/j.devcel.2013.03.020)

Craig JR, Jenkins TG, Carrell DT \& Hotaling JM 2017 Obesity, male infertility, and the sperm epigenome. Fertility and Sterility 107 848-859. (https://doi.org/10.1016/j.fertnstert.2017.02.115)

Das PP, Bagijn MP, Goldstein LD, Woolford JR, Lehrbach NJ, Sapetschnig A Buhecha HR, Gilchrist MJ, Howe KL, Stark R et al. 2008 Piwi and
piRNAs act upstream of an endogenous siRNA pathway to suppress Tc3 transposon mobility in the Caenorhabditis elegans germline. Molecular Cell 31 79-90. (https://doi.org/10.1016/j.molcel.2008.06.003)

de Oliveira RV, Dogan S, Belser LE, Kaya A, Topper E, Moura A, Thibaudeau G \& Memili E 2013 Molecular morphology and function of bull spermatozoa linked to histones and associated with fertility. Reproduction 146 263-272. (https://doi.org/10.1530/REP-12-0399)

de Waal $E$, Yamazaki $Y$, Ingale $P$, Bartolomei $M$, Yanagimachi $\mathbf{R}$ \& McCarrey JR 2012 Primary epimutations introduced during intracytoplasmic sperm injection (ICSI) are corrected by germlinespecific epigenetic reprogramming. PNAS 109 4163-4168. (https://doi. org/10.1073/pnas.1201990109)

Dean W, Santos F, Stojkovic M, Zakhartchenko V, Walter J, Wolf E \& Reik W 2001 Conservation of methylation reprogramming in mammalian development: aberrant reprogramming in cloned embryos. PNAS 98 13734-13738. (https://doi.org/10.1073/pnas.241522698)

Deshmukh RS, Ostrup O, Ostrup E, Vejlsted M, Niemann H, LucasHahn A, Petersen B, Li J, Callesen H \& Hyttel P 2011 DNA methylation in porcine preimplantation embryos developed in vivo and produced by in vitro fertilization, parthenogenetic activation and somatic cell nuclear transfer. Epigenetics 6 177-187. (https://doi.org/10.4161/epi.6.2.13519)

Dominissini D, Moshitch-Moshkovitz S, Schwartz S, Salmon-Divon M, Ungar L, Osenberg S, Cesarkas K, Jacob-Hirsch J, Amariglio N, Kupiec M et al. 2012 Topology of the human and mouse m6A RNA methylomes revealed by m6A-seq. Nature 485 201-206. (https://doi. org/10.1038/nature11112)

Dong H, Wang Y, Zou Z, Chen L, Shen C, Xu S, Zhang J, Zhao F, Ge S, Gao Q et al. 2016 Abnormal methylation of imprinted genes and cigarette smoking: assessment of their association with the risk of male infertility. Reproductive Sciences 24 114-123. (https://doi. org/10.1177/1933719116650755)

Dukowic-Schulze S, Sundararajan A, Ramaraj T, Kianian S, Pawlowski WP, Mudge J \& Chen C 2016 Novel meiotic miRNAs and indications for a role of PhasiRNAs in meiosis. Frontiers in Plant Science 7 762. (https:// doi.org/10.3389/fpls.2016.00762)

Dumasia K, Kumar A, Kadam L \& Balasinor NH 2015 Effect of estrogen receptor-subtype-specific ligands on fertility in adult male rats. Journal of Endocrinology 225 169-180. (https://doi.org/10.1530/JOE-15-0045)

Dumasia K, Kumar A, Deshpande S, Sonawane S \& Balasinor NH 2016 Differential roles of estrogen receptors, ESR1 and ESR2, in adult rat spermatogenesis. Molecular and Cellular Endocrinology 428 89-100. (https://doi.org/10.1016/j.mce.2016.03.024)

Dumasia K, Kumar A, Deshpande S \& Balasinor NH 2017a Estrogen signaling, through estrogen receptor beta, regulates DNA methylation and its machinery in male germ line in adult rats. Epigenetics 12 476-483. (https://doi.org/10.1080/15592294.2017.1309489)

Dumasia K, Kumar A, Deshpande S \& Balasinor NH 2017b Estrogen, through estrogen receptor 1, regulates histone modifications and chromatin remodeling during spermatogenesis in adult rats. Epigenetics 12 953-963. (https://doi.org/10.1080/15592294.2017.1382786)

Eirin-Lopez JM, Frehlick LJ \& Ausio J 2006 Protamines, in the footsteps of linker histone evolution. Journal of Biological Chemistry 281 1-4. (https://doi.org/10.1074/jbc.R500018200)

Fabia J \& Thuy TD 1974 Occupation of father at time of birth of children dying of malignant diseases. British Journal of Preventive and Social Medicine 28 98-100. (https://doi.org/10.1136/jech.28.2.98)

Fan Y, Yang J, Mathioni SM, Yu J, Shen J, Yang X, Wang L, Zhang Q, Cai Z, Xu C et al. 2016 PMS1T, producing phased small-interfering RNAs, regulates photoperiod-sensitive male sterility in rice. PNAS 113 15144-15149. (https://doi.org/10.1073/pnas.1619159114)

Filby AL, Neuparth T, Thorpe KL, Owen R, Galloway TS \& Tyler CR 2007 Health impacts of estrogens in the environment, considering complex mixture effects. Environmental Health Perspectives 115 1704-1710. (https://doi.org/10.1289/ehp.10443)

Fortunato A, Leo R \& Liguori F 2013 Effects of cryostorage on human sperm chromatin integrity. Zygote 21 330-336. (https://doi.org/10.1017/ S0967199412000032)

Fu Y, Dominissini D, Rechavi G \& He C 2014 Gene expression regulation mediated through reversible m(6)A RNA methylation. Nature Reviews Genetics 15 293-306. (https://doi.org/10.1038/nrg3724)

Galindo MI, Pueyo JI, Fouix S, Bishop SA \& Couso JP 2007 Peptides encoded by short ORFs control development and define a new 
eukaryotic gene family. PLoS Biology 5 e106. (https://doi.org/10.1371/ journal.pbio.0050106)

Geula S, Moshitch-Moshkovitz S, Dominissini D, Mansour AA, Kol N, Salmon-Divon M, Hershkovitz V, Peer E, Mor N, Manor YS et al. 2015 Stem cells. m6A mRNA methylation facilitates resolution of naive pluripotency toward differentiation. Science 347 1002-1006. (https:// doi.org/10.1126/science.1261417)

Gkountela S \& Clark AT 2014 A big surprise in the little zygote: the curious business of losing methylated cytosines. Cell Stem Cell 15 393-394. (https://doi.org/10.1016/j.stem.2014.09.005)

Godia M, Swanson G \& Krawetz SA 2018 A history of why fathers' RNA matters. Biology of Reproduction. 99 147-159. (https://doi.org/10.1093/ biolre/ioy007)

Goodrich R, Johnson G \& Krawetz SA 2007 The preparation of human spermatozoal RNA for clinical analysis. Archives of Andrology 53 161-167. (https://doi.org/10.1080/01485010701216526)

Goodrich RJ, Anton E \& Krawetz SA 2013 Isolating mRNA and small noncoding RNAs from human sperm. Methods in Molecular Biology 927 385-396. (https://doi.org/10.1007/978-1-62703-038-0_33)

Gries J, Schumacher D, Arand J, Lutsik P, Markelova MR, Fichtner I, Walter J, Sers C \& Tierling S 2013 Bi-PROF: bisulfite profiling of target regions using 454 GS FLX Titanium technology. Epigenetics 8 765-771. (https://doi.org/10.4161/epi.25242)

Guo F, Li X, Liang D, Li T, Zhu P, Guo H, Wu X, Wen L, Gu TP, Hu B et al. 2014a Active and passive demethylation of male and female pronuclear DNA in the mammalian zygote. Cell Stem Cell 15 447-459. (https://doi. org/10.1016/j.stem.2014.08.003)

Guo H, Zhu P, Yan L, Li R, Hu B, Lian Y, Yan J, Ren X, Lin S, Li J et al. $2014 b$ The DNA methylation landscape of human early embryos. Nature $\mathbf{5 1 1}$ 606-610. (https://doi.org/10.1038/nature13544)

Hamada A, Esteves SC, Nizza M \& Agarwal A 2012 Unexplained male infertility: diagnosis and management. International Brazilian Journal of Urology 38 576-594. (https://doi.org/10.1590/S167755382012000500002)

Hammoud SS, Nix DA, Zhang H, Purwar J, Carrell DT \& Cairns BR 2009 Distinctive chromatin in human sperm packages genes for embryo development. Nature 460 473-478. (https://doi.org/10.1038/ nature08162)

Hanna CW \& Kelsey G 2017 Genomic imprinting beyond DNA methylation: a role for maternal histones. Genome Biology 18177. (https://doi.org/10.1186/s13059-017-1317-9)

He X, Ou C, Xiao Y, Han Q, Li H \& Zhou S 2017 LncRNAs: key players and novel insights into diabetes mellitus. Oncotarget 8 71325-71341.

Holliday R 1987 The inheritance of epigenetic defects. Science 238 163-170. (https://doi.org/10.1126/science.3310230)

Houwing S, Kamminga LM, Berezikov E, Cronembold D, Girard A, van den Elst H, Filippov DV, Blaser H, Raz E, Moens CB et al. 2007 A role for Piwi and piRNAs in germ cell maintenance and transposon silencing in Zebrafish. Cell 129 69-82. (https://doi.org/10.1016/j. cell.2007.03.026)

Huang Y, Zhang JL, Yu XL, Xu TS, Wang ZB \& Cheng XC 2013 Molecular functions of small regulatory noncoding RNA. Biochemistry $\mathbf{7 8}$ 221-230. (https://doi.org/10.1134/S0006297913030024)

Iqbal K, Tran DA, Li AX, Warden C, Bai AY, Singh P, Wu X, Pfeifer GP \& Szabo PE 2015 Deleterious effects of endocrine disruptors are corrected in the mammalian germline by epigenome reprogramming. Genome Biology 16 59. (https://doi.org/10.1186/s13059-015-0619-z)

Ito S, Shen L, Dai Q, Wu SC, Collins LB, Swenberg JA, He C \& Zhang Y 2011 Tet proteins can convert 5-methylcytosine to 5-formylcytosine and 5-carboxylcytosine. Science 333 1300-1303. (https://doi.org/10.1126/ science.1210597)

Jang HS, Shin WJ, Lee JE \& Do JT 2017 CpG and non-CpG methylation in epigenetic gene regulation and brain function. Genes 28 E148. (https:// doi.org/10.3390/genes8060148)

Jenkins TG, Aston KI, James ER \& Carrell DT 2017 Sperm epigenetics in the study of male fertility, offspring health, and potential clinical applications. Systems Biology in Reproductive Medicine 63 69-76. (https://doi.org/10.1080/19396368.2016.1274791)

Jia G, Fu Y, Zhao X, Dai Q, Zheng G, Yang Y, Yi C, Lindahl T, Pan T, Yang YG et al. 2011 N6-methyladenosine in nuclear RNA is a major substrate of the obesity-associated FTO. Nature Chemical Biology 7 885-887. (https://doi.org/10.1038/nchembio.687)
Jiang GJ, Zhang T, An T, Zhao DD, Yang XY, Zhang DW, Zhang Y, Mu QQ, Yu N, Ma XS \& Gao SH 2016 Differential expression of long noncoding RNAs between sperm samples from diabetic and non-diabetic mice. PLoS ONE 11 e0154028. (https://doi.org/10.1371/journal.pone.0154028)

Jodar M, Sendler E, Moskovtsev SI, Librach CL, Goodrich R, Swanson S, Hauser R, Diamond MP \& Krawetz SA 2015 Absence of sperm RNA elements correlates with idiopathic male infertility. Science Translational Medicine 7 295re296. (https://doi.org/10.1126/scitranslmed.aab1287)

Johnson GD, Mackie P, Jodar M, Moskovtsev S \& Krawetz SA 2015 Chromatin and extracellular vesicle associated sperm RNAs. Nucleic Acids Research 43 6847-6859. (https://doi.org/10.1093/nar/gkv591)

Kaneda M, Okano M, Hata K, Sado T, Tsujimoto N, Li E \& Sasaki H 2004 Essential role for de novo DNA methyltransferase Dnmt3a in paternal and maternal imprinting. Nature 429 900-903. (https://doi.org/10.1038/ nature02633)

Katib A 2015 Mechanisms linking obesity to male infertility. Central European Journal of Urology 68 79-85. (https://doi.org/10.1016/j. eururo.2015.05.013)

Kino T, Hurt DE, Ichijo T, Nader N \& Chrousos GP 2010 Noncoding RNA gas5 is a growth arrest- and starvation-associated repressor of the glucocorticoid receptor. Science Signaling 3 ra8. (https://doi. org/10.1126/scisignal.2000568)

Kobayashi H, Sato A, Otsu E, Hiura H, Tomatsu C, Utsunomiya T, Sasaki H, Yaegashi N \& Arima T 2007 Aberrant DNA methylation of imprinted loci in sperm from oligospermic patients. Human Molecular Genetics $\mathbf{1 6}$ 2542-2551. (https://doi.org/10.1093/hmg/ddm187)

Kobayashi N, Miyauchi N, Tatsuta N, Kitamura A, Okae H, Hiura H, Sato A, Utsunomiya T, Yaegashi N, Nakai K et al. 2017 Factors associated with aberrant imprint methylation and oligozoospermia. Scientific Reports 7 42336. (https://doi.org/10.1038/srep42336)

Kondo T, Hashimoto Y, Kato K, Inagaki S, Hayashi S \& Kageyama Y 2007 Small peptide regulators of actin-based cell morphogenesis encoded by a polycistronic mRNA. Nature Cell Biology 9 660-665. (https://doi. org/10.1038/ncb1595)

Kondo T, Plaza S, Zanet J, Benrabah E, Valenti P, Hashimoto Y, Kobayashi S, Payre F \& Kageyama Y 2010 Small peptides switch the transcriptional activity of Shavenbaby during Drosophila embryogenesis. Science 329 336-339. (https://doi.org/10.1126/science.1188158)

Krausz C, Escamilla AR \& Chianese C 2015 Genetics of male infertility: from research to clinic. Reproduction 150 R159-R174. (https://doi. org/10.1530/REP-15-0261)

Krejci J, Stixova L, Pagacova E, Legartova S, Kozubek S, Lochmanova G, Zdrahal Z, Sehnalova P, Dabravolski S, Hejatko J et al. 2015 Posttranslational modifications of histones in human sperm. Journal of Cellular Biochemistry 116 2195-2209. (https://doi.org/10.1002/ jcb.25170)

Kropp J, Carrillo JA, Namous H, Daniels A, Salih SM, Song J \& Khatib H 2017 Male fertility status is associated with DNA methylation signatures in sperm and transcriptomic profiles of bovine preimplantation embryos. BMC Genomics 18 280. (https://doi.org/10.1186/s12864-017-3673-y)

Kumar A, Dumasia K, Deshpande S \& Balasinor NH 2017 Direct regulation of genes involved in sperm release by estrogen and androgen through their receptors and coregulators. Journal of Steroid Biochemistry and Molecular Biology 171 66-74. (https://doi.org/10.1016/j. jsbmb.2017.02.017)

Kung JT, Colognori D \& Lee JT 2013 Long noncoding RNAs: past, present, and future. Genetics 193 651-669. (https://doi.org/10.1534/ genetics.112.146704)

Kutchy NA, Menezes ESB, Chiappetta A, Tan W, Wills RW, Kaya A, Topper E, Moura AA, Perkins AD \& Memili E 2018 Acetylation and methylation of sperm histone 3 lysine 27 (H3K27ac and H3K27me3) are associated with bull fertility. Andrologia 50 e12915. (https://doi. org/10.1111/and.12915)

Kutchy NA, Velho A, Menezes ESB, Jacobsen M, Thibaudeau G, Wills RW, Moura A, Kaya A, Perkins A \& Memili E 2017 Testis specific histone $2 \mathrm{~B}$ is associated with sperm chromatin dynamics and bull fertility-a pilot study. Reproductive Biology and Endocrinology 15 59. (https://doi. org/10.1186/s12958-017-0274-1)

Lahn BT, Tang ZL, Zhou J, Barndt RJ, Parvinen M, Allis CD \& Page DC 2002 Previously uncharacterized histone acetyltransferases implicated in mammalian spermatogenesis. PNAS 99 8707-8712. (https://doi. org/10.1073/pnas.082248899) 
Lambrot R, Xu C, Saint-Phar S, Chountalos G, Cohen T, Paquet M, Suderman M, Hallett M \& Kimmins S 2013 Low paternal dietary folate alters the mouse sperm epigenome and is associated with negative pregnancy outcomes. Nature Communications 4 2889. (https://doi. org/10.1038/ncomms3889)

Laqqan M, Solomayer EF \& Hammadeh M 2017a Aberrations in sperm DNA methylation patterns are associated with abnormalities in semen parameters of subfertile males. Reproductive Biology 17 246-251. (https://doi.org/10.1016/j.repbio.2017.05.010)

Laqqan M, Tierling S, Alkhaled Y, Porto CL, Solomayer EF \& Hammadeh ME $2017 b$ Aberrant DNA methylation patterns of human spermatozoa in current smoker males. Reproductive Toxicology 71 126-133. (https://doi. org/10.1016/j.reprotox.2017.05.010)

Laurentino S, Beygo J, Nordhoff V, Kliesch S, Wistuba J, Borgmann J, Buiting K, Horsthemke B \& Gromoll J 2015 Epigenetic germline mosaicism in infertile men. Human Molecular Genetics 24 1295-1304. (https://doi.org/10.1093/hmg/ddu540)

Laurentino S, Borgmann J \& Gromoll J 2016 On the origin of sperm epigenetic heterogeneity. Reproduction 151 R71-R78. (https://doi. org/10.1530/REP-15-0436)

Lees-Murdock DJ \& Walsh CP 2008 DNA methylation reprogramming in the germ line. Epigenetics 3 5-13. (https://doi.org/10.4161/epi.3.1.5553)

Li JY, Lees-Murdock DJ, Xu GL \& Walsh CP 2004 Timing of establishment of paternal methylation imprints in the mouse. Genomics 84 952-960. (https://doi.org/10.1016/j.ygeno.2004.08.012)

Liebers R, Rassoulzadegan M \& Lyko F 2014 Epigenetic regulation by heritable RNA. PLoS Genetics 10 e1004296. (https://doi.org/10.1371/ journal.pgen.1004296)

Lim U \& Song MA 2012 Dietary and lifestyle factors of DNA methylation. Methods in Molecular Biology 863 359-376. (https://doi. org/10.1007/978-1-61779-612-8_23)

Lin S, Choe J, Du P, Triboulet R \& Gregory RI 2016 The m(6)A methyltransferase METTL3 promotes translation in human cancer cells. Molecular Cell 62 335-345. (https://doi.org/10.1016/j. molcel.2016.03.021)

Lin Z, Hsu PJ, Xing X, Fang J, Lu Z, Zou Q, Zhang KJ, Zhang X, Zhou Y, Zhang T et al. 2017 Mettl3-/Mettl14-mediated mRNA N6methyladenosine modulates murine spermatogenesis. Cell Research $\mathbf{2 7}$ 1216-1230. (https://doi.org/10.1038/cr.2017.117)

Linder B, Grozhik AV, Olarerin-George AO, Meydan C, Mason CE \& Jaffrey SR 2015 Single-nucleotide-resolution mapping of m6A and m6Am throughout the transcriptome. Nature Methods 12 767-772. (https://doi.org/10.1038/nmeth.3453)

Liu N \& Pan T 2015 RNA epigenetics. Translational Research 165 28-35. (https://doi.org/10.1016/j.trsl.2014.04.003)

Liu Y, Sun Y, Li Y, Bai H, Xue F, Xu S, Xu H, Shi L, Yang N \& Chen J 2017 Analyses of long non-coding RNA and mRNA profiling using RNA sequencing in chicken testis with extreme sperm motility. Scientific Reports 7 9055. (https://doi.org/10.1038/s41598-017-08738-9)

Luense LJ, Wang X, Schon SB, Weller AH, Lin Shiao E, Bryant JM, Bartolomei MS, Coutifaris C, Garcia BA et al. 2016 Comprehensive analysis of histone post-translational modifications in mouse and human male germ cells. Epigenetics and Chromatin 9 24. (https://doi. org/10.1186/s13072-016-0072-6)

Luk AC, Chan WY, Rennert OM \& Lee TL 2014 Long noncoding RNAs in spermatogenesis: insights from recent high-throughput transcriptome studies. Reproduction 147 R131-R141. (https://doi.org/10.1530/REP-130594)

Magny EG, Pueyo JI, Pearl FM, Cespedes MA, Niven JE, Bishop SA \& Couso JP 2013 Conserved regulation of cardiac calcium uptake by peptides encoded in small open reading frames. Science 341 1116-1120. (https://doi.org/10.1126/science.1238802)

Marques CJ, Carvalho F, Sousa M \& Barros A 2004 Genomic imprinting in disruptive spermatogenesis. Lancet 363 1700-1702. (https://doi. org/10.1016/S0140-6736(04)16256-9)

Marques CJ, Costa P, Vaz B, Carvalho F, Fernandes S, Barros A \& Sousa M 2008 Abnormal methylation of imprinted genes in human sperm is associated with oligozoospermia. Molecular Human Reproduction $\mathbf{1 4}$ 67-74. (https://doi.org/10.1093/molehr/gam093)

Mattick JS 2001 Non-coding RNAs: the architects of eukaryotic complexity. $E M B O$ Reports 2 986-991. (https://doi.org/10.1093/embo-reports/ kve230)
Meikar O, Da Ros M, Korhonen H \& Kotaja N 2011 Chromatoid body and small RNAs in male germ cells. Reproduction 142 195-209. (https://doi. org/10.1530/REP-11-0057)

Meistrich ML, Mohapatra B, Shirley CR \& Zhao M 2003 Roles of transition nuclear proteins in spermiogenesis. Chromosoma 111 483-488. (https:// doi.org/10.1007/s00412-002-0227-z)

Messerschmidt DM, Knowles BB \& Solter D 2014 DNA methylation dynamics during epigenetic reprogramming in the germline and preimplantation embryos. Genes and Development 28 812-828. (https://doi.org/10.1101/gad.234294.113)

Meyer KD \& Jaffrey SR 2014 The dynamic epitranscriptome: N6methyladenosine and gene expression control. Nature Reviews Molecular Cell Biology 15 313-326. (https://doi.org/10.1038/nrm3785)

Miller D, Brinkworth M \& Iles D 2010 Paternal DNA packaging in spermatozoa: more than the sum of its parts? DNA, histones, protamines and epigenetics. Reproduction 139 287-301. (https://doi.org/10.1530/ REP-09-0281)

Morselli M, Pastor WA, Montanini B, Nee K, Ferrari R, Fu K, Bonora G, Rubbi L, Clark AT, Ottonello $\mathbf{S}$ et al. 2015 In vivo targeting of de novo DNA methylation by histone modifications in yeast and mouse. Elife $\mathbf{4}$ e06205. (https://doi.org/10.7554/eLife.06205)

Nasri F, Gharesi-Fard B, Namavar Jahromi B, Farazi-Fard MA, Banaei M, Davari M, Ebrahimi S \& Anvar Z 2017 Sperm DNA methylation of H19 imprinted gene and male infertility. Andrologia 49 e12766. (https://doi. org/10.1111/and.12766)

Neri F, Incarnato D, Krepelova A, Parlato C \& Oliviero S 2016 Methylationassisted bisulfite sequencing to simultaneously map $5 \mathrm{fC}$ and $5 \mathrm{caC}$ on a genome-wide scale for DNA demethylation analysis. Nature Protocols 11 1191-1205. (https://doi.org/10.1038/nprot.2016.063)

O'Doherty AM \& McGettigan PA 2014 Epigenetic processes in the male germline. Reproduction, Fertility and Development. 27 725-738. (https://doi.org/10.1071/RD14167)

O'Doherty AM, O'Shea LC \& Fair T 2012 Bovine DNA methylation imprints are established in an oocyte size-specific manner, which are coordinated with the expression of the DNMT3 family proteins. Biology of Reproduction 86 67. (https://doi.org/10.1095/ biolreprod.111.094946)

O'Doherty AM, Magee DA, O'Shea LC, Forde N, Beltman ME, Mamo S \& Fair T 2015 DNA methylation dynamics at imprinted genes during bovine pre-implantation embryo development. BMC Developmental Biology 15 13. (https;//doi.org/10.1186/s12861-015-0060-2)

Okano M, Bell DW, Haber DA \& Li E 1999 DNA methyltransferases Dnmt3a and Dnmt3b are essential for de novo methylation and mammalian development. Cell 99 247-257. (https://doi.org/10.1016/ S0092-8674(00)81656-6)

Oliva R \& Mezquita C 1982 Histone H4 hyperacetylation and rapid turnover of its acetyl groups in transcriptionally inactive rooster testis spermatids. Nucleic Acids Research 10 8049-8059. (https://doi. org/10.1093/nar/10.24.8049)

Ost A, Lempradl A, Casas E, Weigert M, Tiko T, Deniz M, Pantano L, Boenisch U, Itskov PM, Stoeckius M et al. 2014 Paternal diet defines offspring chromatin state and intergenerational obesity. Cell 159 1352-1364. (https://doi.org/10.1016/j.cell.2014.11.005)

Ouko LA, Shantikumar K, Knezovich J, Haycock P, Schnugh DJ \& Ramsay M 2009 Effect of alcohol consumption on CpG methylation in the differentially methylated regions of H19 and IG-DMR in male gametes: implications for fetal alcohol spectrum disorders. Alcoholism: Clinical and Experimental Research 33 1615-1627. (https://doi. org/10.1111/j.1530-0277.2009.00993.x)

Pacheco SE, Houseman EA, Christensen BC, Marsit CJ, Kelsey KT, Sigman M \& Boekelheide K 2011 Integrative DNA methylation and gene expression analyses identify DNA packaging and epigenetic regulatory genes associated with low motility sperm. PLoS ONE 6 e20280. (https:// doi.org/10.1371/journal.pone.0020280)

Pantano L, Jodar M, Bak M, Ballesca JL, Tommerup N, Oliva R \& Vavouri T 2015 The small RNA content of human sperm reveals pseudogenederived piRNAs complementary to protein-coding genes. RNA 21 1085-1095. (https://doi.org/10.1261/rna.046482.114)

Poplinski A, Tuttelmann F, Kanber D, Horsthemke B \& Gromoll J 2010 Idiopathic male infertility is strongly associated with aberrant methylation of MEST and IGF2/H19 ICR1. International Journal of Andrology 33 642-649. (10.1111/j.1365-2605.2009.01000.x) 
Prokopuk L, Western PS \& Stringer JM 2015 Transgenerational epigenetic inheritance: adaptation through the germline epigenome? Epigenomics 7 829-846. (https://doi.org/10.2217/epi.15.36)

Radford EJ, Ito M, Shi H, Corish JA, Yamazawa K, Isganaitis E, Seisenberger S, Hore TA, Reik W, Erkek S et al. 2014 In utero undernourishment perturbs the adult sperm methylome and intergenerational metabolism. Science 345(6198) 1255903. (https://doi.org/10.1126/science.1255903)

Ramon M, Jimenez-Rabadan P, Garcia-Alvarez O, Maroto-Morales A, Soler AJ, Fernandez-Santos MR, Perez-Guzman MD \& Garde JJ 2014 Understanding sperm heterogeneity: biological and practical implications. Reproduction in Domestic Animals 49 (Supplement 4) 30-36. (https://doi.org/10.1111/rda.12404)

Rando OJ \& Simmons RA 2015 I'm eating for two: parental dietary effects on offspring metabolism. Cell 161 93-105. (https://doi.org/10.1016/j. cell.2015.02.021)

Rathke C, Baarends WM, Awe S \& Renkawitz-Pohl R 2014 Chromatin dynamics during spermiogenesis. Biochimica et Biophysica Acta 1839 155-168. (https://doi.org/10.1016/j.bbagrm.2013.08.004)

Reik W, Dean W \& Walter J 2001 Epigenetic reprogramming in mammalian development. Science 293 1089-1093. (https://doi.org/10.1126/ science.1063443)

Rohrig H, Schmidt J, Miklashevichs E, Schell J \& John M 2002 Soybean ENOD40 encodes two peptides that bind to sucrose synthase. PNAS 99 1915-1920. (https://doi.org/10.1073/pnas.022664799)

Salas-Huetos A, Blanco J, Vidal F, Grossmann M, Pons MC, Garrido N \& Anton E 2016 Spermatozoa from normozoospermic fertile and infertile individuals convey a distinct miRNA cargo. Andrology 4 1028-1036. (https://doi.org/10.1111/andr.12276)

Sasaki H \& Matsui Y 2008 Epigenetic events in mammalian germ-cell development: reprogramming and beyond. Nature Reviews Genetics 9 129-140. (https://doi.org/10.1038/nrg2295)

Schagdarsurengin U \& Steger K 2016 Epigenetics in male reproduction: effect of paternal diet on sperm quality and offspring health. Nature Reviews Urology 13 584-595. (https://doi.org/10.1038/nrurol.2016.157)

Schuster A, Tang C, Xie Y, Ortogero N, Yuan S \& Yan W 2016 SpermBase: a database for sperm-borne RNA contents. Biology of Reproduction 95 99. (https://doi.org/10.1095/biolreprod.116.142190)

Seisenberger S, Andrews S, Krueger F, Arand J, Walter J, Santos F, Popp C, Thienpont B, Dean W \& Reik W 2012 The dynamics of genome-wide DNA methylation reprogramming in mouse primordial germ cells. Molecular Cell 48 849-862. (https://doi.org/10.1016/j.molcel.2012.11.001)

Shea JM, Serra RW, Carone BR, Shulha HP, Kucukural A, Ziller MJ, Vallaster MP, Gu H, Tapper AR, Gardner PD et al. 2015 Genetic and epigenetic variation, but not diet, shape the sperm methylome. Developmental Cell $35 \quad 750-758 . \quad$ (https://doi.org/10.1016/j. devcel.2015.11.024)

Singh P, Li AX, Tran DA, Oates N, Kang ER, Wu X \& Szabo PE 2013 De novo DNA methylation in the male germ line occurs by default but is excluded at sites of H3K4 methylation. Cell Reports 4 205-219. (https:// doi.org/10.1016/j.celrep.2013.06.004)

Singh AK, Tomarz S, Chaudhari AR, Sinqh R \& Verma N 2014 Type 2 diabetes mellitus affects male fertility potential. Indian Journal of Physiology and Pharmacology 58 403-406.

Sleutels F, Zwart R \& Barlow DP 2002 The non-coding Air RNA is required for silencing autosomal imprinted genes. Nature 415 810-813. (https:// doi.org/10.1038/415810a)

Smith ZD \& Meissner A 2013 DNA methylation: roles in mammalian development. Nature Reviews Genetics 14 204-220. (https://doi. org/10.1038/nrg3354)

Soubry A, Hoyo C, Jirtle RL \& Murphy SK 2014 A paternal environmental legacy: evidence for epigenetic inheritance through the male germ line. Bioessays 36 359-371. (https://doi.org/10.1002/bies.201300113)

Stewart KR, Veselovska L \& Kelsey G 2016 Establishment and functions of DNA methylation in the germline. Epigenomics 8 1399-1413. (https:// doi.org/10.2217/epi-2016-0056)

Stouder C, Somm E \& Paoloni-Giacobino A 2011 Prenatal exposure to ethanol: a specific effect on the $\mathrm{H} 19$ gene in sperm. Reproductive Toxicology 31 507-512. (https://doi.org/10.1016/j.reprotox.2011.02.009)

Stuppia L, Franzago M, Ballerini P, Gatta V \& Antonucci I 2015 Epigenetics and male reproduction: the consequences of paternal lifestyle on fertility, embryo development, and children lifetime health. Clinical Epigenetics 7 120. (https://doi.org/10.1186/s13148-015-0155-4)
Tang MC, Jacobs SA, Mattiske DM, Soh YM, Graham AN, Tran A, Lim SL, Hudson DF, Kalitsis P, O'Bryan MK et al. 2015 Contribution of the two genes encoding histone variant h3.3 to viability and fertility in mice. PLoS Genetics 11 e1004964. (https://doi.org/10.1371/journal. pgen.1004964)

Tang C, Klukovich R, Peng H, Wang Z, Yu T, Zhang Y, Zheng H, Klungland A \&Yan W 2018 ALKBH5-dependent m6A demethylation controls splicing and stability of long $3^{\prime}$-UTR mRNAs in male germ cells. PNAS 115 E325-E333. (https;//doi.org/10.1073/pnas.1717794115)

Teperek M, Simeone A, Gaggioli V, Miyamoto K, Allen GE, Erkek S, Kwon T, Marcotte EM, Zegerman P, Bradshaw CR et al. 2016 Sperm is epigenetically programmed to regulate gene transcription in embryos. Genome Research 26 1034-1046. (https://doi.org/10.1101/ gr.201541.115)

Tomizawa S, Nowacka-Woszuk J \& Kelsey G 2012 DNA methylation establishment during oocyte growth: mechanisms and significance. International Journal of Developmental Biology 56 867-875. (https://doi. org/10.1387/ijdb.120152gk)

Ueda J, Harada A, Urahama T, Machida S, Maehara K, Hada M, Makino Y, Nogami J, Horikoshi N, Osakabe A et al. 2017 Testis-specific histone variant $\mathrm{H} 3$ t gene is essential for entry into spermatogenesis. Cell Reports 18 593-600. (https://doi.org/10.1016/j.celrep.2016.12.065)

Urdinguio RG, Bayon GF, Dmitrijeva M, Torano EG, Bravo C, Fraga MF, Bassas L, Larriba S \& Fernandez AF 2015 Aberrant DNA methylation patterns of spermatozoa in men with unexplained infertility. Human Reproduction 30 1014-1028. (https://doi.org/10.1093/humrep/ dev053)

Verma A, Rajput S, Kumar S, De S, Chakravarty AK, Kumar R \& Datta TK 2015 Differential histone modification status of spermatozoa in relation to fertility of buffalo bulls. Journal of Cellular Biochemistry 116 743-753. (https://doi.org/10.1002/jcb.25029)

Vieweg M, Dvorakova-Hortova K, Dudkova B, Waliszewski P, Otte M, Oels B, Hajimohammad A, Turley H, Schorsch M, Schuppe HC et al. 2015 Methylation analysis of histone H4K12ac-associated promoters in sperm of healthy donors and subfertile patients. Clinical Epigenetics 7 31. (https://doi.org/10.1186/s13148-015-0058-4)

Ward WS \& Coffey DS 1991 DNA packaging and organization in mammalian spermatozoa: comparison with somatic cells. Biology of Reproduction 44 569-574. (https://doi.org/10.1095/ biolreprod44.4.569)

Whitelaw E 2015 Sperm DNA methylation: not a vehicle for dietary reprogramming of offspring? Developmental Cell 35 668-669. (https:// doi.org/10.1016/j.devcel.2015.12.005)

Wiebe JC, Santana A, Medina-Rodriguez N, Hernandez M, Novoa J, Mauricio D, Wagner AM \& T1DGC 2014 Fertility is reduced in women and in men with type 1 diabetes: results from the Type 1 Diabetes Genetics Consortium (T1DGC). Diabetologia 57 2501-2504. (https:// doi.org/10.1007/s00125-014-3376-8)

Wu H \& Zhang Y 2014 Reversing DNA methylation: mechanisms, genomics, and biological functions. Cell 156 45-68. (https://doi. org/10.1016/j.cell.2013.12.019)

Yang Y, Huang W, Huang JT, Shen F, Xiong J, Yuan EF, Qin SS, Zhang M, Feng YQ, Yuan BF et al. 2016 Increased N6-methyladenosine in human sperm RNA as a risk factor for asthenozoospermia. Scientific Reports $\mathbf{6}$ 24345. (https://doi.org/10.1038/srep24345)

Yoder JA, Soman NS, Verdine GL \& Bestor TH 1997 DNA (cytosine-5)methyltransferases in mouse cells and tissues. Studies with a mechanismbased probe. Journal of Molecular Biology 270 385-395. (https://doi. org/10.1006/jmbi.1997.1125)

Zalensky AO, Siino JS, Gineitis AA, Zalenskaya IA, Tomilin NV, Yau P \& Bradbury EM 2002 Human testis/sperm-specific histone H2B (hTSH2B). Molecular cloning and characterization. Journal of Biological Chemistry 277 43474-43480. (https://doi.org/10.1074/jbc.M206065200)

Zeggini E, Weedon MN, Lindgren CM, Frayling TM, Elliott KS, Lango $\mathbf{H}$, Timpson NJ, Perry JR, Rayner NW, Freathy RM et al. 2007 Replication of genome-wide association signals in UK samples reveals risk loci for type 2 diabetes. Science 316 1336-1341. (https://doi.org/10.1126/ science.1142364)

Zhai J, Zhang H, Arikit S, Huang K, Nan GL, Walbot V \& Meyers BC 2015 Spatiotemporally dynamic, cell-type-dependent premeiotic and meiotic phasiRNAs in maize anthers. PNAS 112 3146-3151. (https:// doi.org/10.1073/pnas.1418918112) 
Zhang X, San Gabriel M \& Zini A 2006 Sperm nuclear histone to protamine ratio in fertile and infertile men: evidence of heterogeneous subpopulations of spermatozoa in the ejaculate. Journal of Andrology 27 414-420. (https://doi.org/10.2164/jandrol.05171)

Zhang B, Arun G, Mao YS, Lazar Z, Hung G, Bhattacharjee G, Xiao X, Booth CJ, Wu J, Zhang C et al. 2012 The IncRNA Malat1 is dispensable for mouse development but its transcription plays a cis-regulatory role in the adult. Cell Reports 2 111-123. (https://doi.org/10.1016/j. celrep.2012.06.003)

Zhang C, Gao L \& Xu EY 2016 LncRNA, a new component of expanding RNA-protein regulatory network important for animal sperm development. Seminars in Cell and Developmental Biology 59 110-117. (https://doi.org/10.1016/j.semcdb.2016.06.013)
Zheng G, Dahl JA, Niu Y, Fedorcsak P, Huang CM, Li CJ, Vagbo CB, Shi Y, Wang WL, Song SH et al. 2013 ALKBH5 is a mammalian RNA demethylase that impacts RNA metabolism and mouse fertility. Molecular Cell 49 18-29. (https://doi.org/10.1016/j.molcel.2012.10.015)

Received 5 January 2018

First decision 19 February 2018

Revised manuscript received 19 March 2018

Accepted 1 May 2018 